\title{
Synthesis of Some New 1,2,4-Triazine and 1,2,5-Oxadiazine Derivatives with Antimicrobial Activity
}

\author{
Heba E. Hashem (iD) ${ }^{1}$ and Ahmed M. Abo-Bakr ${ }^{2}$ \\ ${ }^{1}$ Department of Chemistry, Faculty of Women, Ain Shams University, Heliopolis, Cairo 11457, Egypt \\ ${ }^{2}$ Department of Chemistry, Faculty of Science, South Valley University, 83523 Qena, Egypt \\ Correspondence should be addressed to Heba E. Hashem; hebahashem89@yahoo.com
}

Received 19 June 2019; Accepted 21 August 2019; Published 25 September 2019

Academic Editor: Xing-Hai Liu

Copyright (C) 2019 Heba E. Hashem and Ahmed M. Abo-Bakr. This is an open access article distributed under the Creative Commons Attribution License, which permits unrestricted use, distribution, and reproduction in any medium, provided the original work is properly cited.

1,2,4-Triazine and 1,2,5-oxadiazine derivatives 2-12 were obtained from treated 1,3-oxazolone (1) with phenyl hydrazine or hydroxylamine hydrochloride. Chlorotriazine derivative $\mathbf{3}$ undergoing condensation reactions with different reagents produced new fused tetrazolo-triazine and triazino-quinazolinone derivatives. 1,2,5-Oxadiazine has been used as a synthon for the fused pyrazolo-oxadiazine derivative. The constitution of the prepared compounds was built up based on microanalytical and spectral data. Some of the new compounds were assessed for their antimicrobial activity.

\section{Introduction}

The importance of studying the azlactones' chemistry remains unabated because of their uses as intermediates for synthesis of new heterocyclic and fused heterocyclic compounds. 1,2,4-Triazine derivatives exhibit antifungal [1, 2], anti-HIV [3], anticancer [4], anti-inflammatory [5], analgesic [6], and antihypertensive [7] activities, besides their uses as herbicides, pesticides, and dyes [8,9]. The pharmacological efficacy of oxadiazine is also known; derivatives of 1,3,4-oxadiazine exhibit antibacterial, cardiovascular plant growth-regulating, miticidal, nematocidal, insecticidal, and anticonvulsive activities $[10,11]$. In addition, oxadiazines are valuable intermediates in the synthesis of tenidap prodrugs or lactam anti-infection agents, specifically in the synthesis of carbapenems and penems [12-14]. On the contrary, 1,2,5-oxadiazines are not very common heterocyclic systems.

A comprehensive review of the synthesis and reactivity of these systems has been reported by Smalley [15]. In view of these observations, the present work tends to utilize " $(Z)$ 4-(4-methoxybenzylidene)-2-phenyloxazol-5(4H)-one” [16] for the synthesis of new 1,2,5-oxadiazine and 1,2,4-triazine derivatives.

\section{Results and Discussion}

“(Z)-4-(4-Methoxybenzylidene)-2-phenyloxazol-5(4H)-one” (1) is synthesized via reaction of hippuric acid with $p$-anisaldehyde under Perkin-Erlenmeyer reaction conditions as reported in the literature [16].

Reaction of oxazolone 1 with phenyl hydrazine in acetic acid (glacial) and fused sodium acetate afforded the 1,2,4triazine-6(5H)-one derivative (2). Compound 2 could be present in lactam-lactim tautomers $(\mathbf{2 A}$ and $\mathbf{2 B})$, but the lactam form is thermodynamically more stable because the oxo form is more stabilized by $54.4 \mathrm{~kJ} \mathrm{~mol}^{-1}$ than the enol form [17]. The structure of 2 can be deduced from its spectroscopic properties. The IR spectrum showed a band correlated with $\mathrm{C}=\mathrm{O}$ lactam at $1690 \mathrm{~cm}^{-1}$. Furthermore, ${ }^{1} \mathrm{HNMR}$ spectrum showed one broad singlet signal in the downfield region correlated with the $\mathrm{NH}$ proton.

Refluxing of compound 2 with phosphorus oxychloride and phosphorus pentachloride produces the chlorotriazine derivative 3 which is used as a synthon for new triazine derivatives (Scheme 1). Reaction of chlorotriazine 3 with hydrazine hydrate gave the hydrazine derivative 4 . Spectral data of compound $\mathbf{4}$ established its suggested structure. Its IR spectrum exhibited absorption bands belonging to $\mathrm{NH}$, 


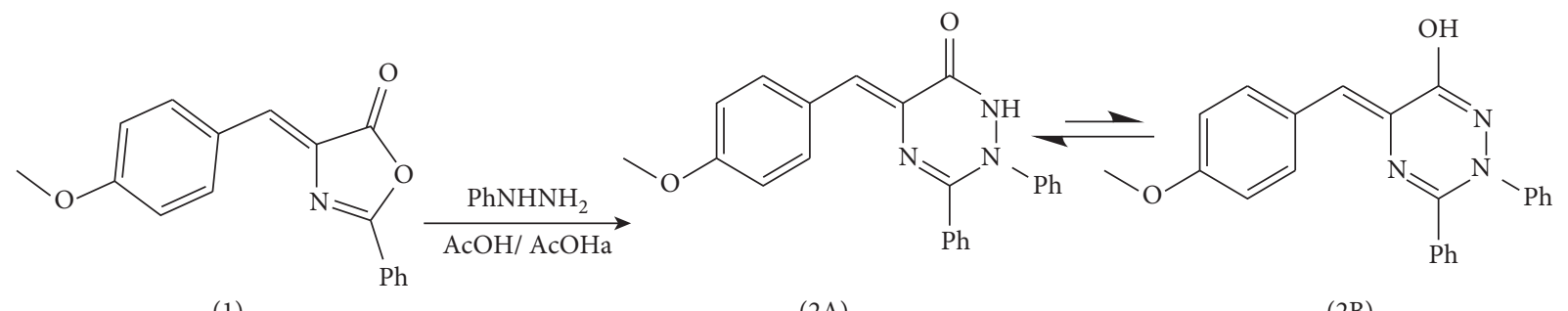

Scheme 1: Synthesis of the triazine derivative from azlactone (1).

$\mathrm{NH}_{2}$, and $\mathrm{C}=\mathrm{N}$ groups. The ${ }^{1} \mathrm{HNMR}$ spectrum exhibited exchangeable broad singlet signals corresponding to the two protons of $\mathrm{NH}_{2}$ and other in the downfield region for the $\mathrm{NH}$ proton.

The structure of compound $\mathbf{4}$ established chemically by refluxing in acetic anhydride yielded the $N, N^{\prime}$-diacetyl derivative 5 (Scheme 2). The structure of compound $\mathbf{5}$, also deduced from the IR spectrum, showed two strong absorption bands at $1726,1701 \mathrm{~cm}^{-1}$ for the $\mathrm{C}=\mathrm{O}$ group (due to symmetric and antisymmetric stretching of the $\mathrm{N}$-diacetyl group).

${ }^{1}$ HNMR spectra exhibited a strong singlet signal $(\delta$ $2.28 \mathrm{ppm}$ ) for the two magnetically equivalent $\mathrm{CH}_{3}$ protons, besides one broad singlet signal for the $\mathrm{NH}$ proton. The mass spectrum confirmed the assigned structure of $\mathbf{5}$ (shown in Experimental).

Also, treatment of chlorotriazine 3 with sodium azide in acetic acid gave 8-(4-methoxybenzylidene)-5,8-dihydro-5,6diphenyltetrazolo[1,5-f] $[1,2,4]$ triazine (6) (Scheme 3).

It is interesting to note that refluxing chlorotriazine (3) with anthranilic acid in "acetic acid" gave the triazinoquinazolinone derivative 7 . The structure of compound 7 is elucidated from the spectral data. Infrared spectrum showed absorption bands characteristic of $v \quad \mathrm{C}=\mathrm{O}$ at $1678 \mathrm{~cm}^{-1}$.

In addition, the ${ }^{1}$ HNMR spectrum of compound 7 showed the different protons from low- to high-field signals for aromatic and aliphatic protons in harmony with the proposed structure. The mass spectrum of compound 7 gave us a good indication about stability of that structure, where the molecular ion peak together with some important peaks was displayed (base peak).

Treatment of oxazolone $\mathbf{1}$ with $\mathrm{NH}_{2} \mathrm{OH} \cdot \mathrm{HCl}$ in pyridine afforded the Z-configurated isomer adduct which could have one of the two possible structures, oxadiazone $\mathbf{Z - 8}$ or imidazolone Z-9 (Scheme 4). The infrared spectrum exhibited two bands at $3240 \mathrm{~cm}^{-1}$ for NH and $1700 \mathrm{~cm}^{-1}$ for the $\mathrm{CO}$ group. The lower frequency of the carbonyl group supported the six-membered oxadiazine structure $\mathbf{Z}-\mathbf{8}$. The ${ }^{1}$ HNMR spectrum of compound Z-8 showed a mixture of lactam-lactim tautomers $\mathbf{Z - 8 a}$ and $\mathbf{Z}-\mathbf{8 b}$ in a $1: 4$ ratio such that two absorption singlet signals for the two methoxy protons are given besides extra exchangeable broad signals due to the $\mathrm{OH}$ proton for $\mathbf{Z}-\mathbf{8 b}$.

The configuration assignment as the Z-isomer may be due to the downfield value of vinyl proton at $\delta 7.17 \mathrm{ppm}$ that is more deshielded by the anisotropic effect of the carbonyl group.
The structure of oxadiazine $\mathbf{Z}-\mathbf{8}$ gets further support by its acetylation with acetic anhydride, giving the $N$-acetyl derivative 10 (Scheme 5).

The infrared spectrum of compound $\mathbf{1 0}$ does not show any absorption bands corresponding to the $\mathrm{NH}$ proton; instead, it exhibits broad bands at $1775 \mathrm{~cm}^{-1}$ for the two $\mathrm{C}=\mathrm{O}$ groups. ${ }^{1} \mathrm{HNMR}$ of compound $\mathbf{1 0}$ shows a good agreement with the proposed structure (shown in Experimental). Further support for the suggested structure gained from its mass spectra revealed the correct molecular ion peak as well as some of the important peaks (base peak).

Alkylation of compound $\mathbf{8}$ via treatment of a solution of compound $\mathbf{8}$ in acetone with ethyl chloroacetate in the presence of potassium carbonate yielded the carboxylic acid derivative 11. IR of compound $\mathbf{1 1}$ showed absorption bands at $3432 \mathrm{~cm}^{-1}$ for $v \mathrm{OH}$ as well as the strong absorption band at $1696 \mathrm{~cm}^{-1}$ for the $\mathrm{C}=\mathrm{O}$ group. Moreover, the ${ }^{1} \mathrm{HNMR}$ spectrum displayed a singlet signal of the two methylene protons at $3.83 \mathrm{ppm}$ and a broad singlet signal correlated with the $\mathrm{COOH}$ proton.

Also, refluxing 11 with $\mathrm{N}_{2} \mathrm{H}_{4} \cdot \mathrm{H}_{2} \mathrm{O}$ in ethanol furnished the unexpected fused pyrazolo-oxadiazine derivative 12 . The structure of compound $\mathbf{1 2}$ can be deduced from spectral data. The infrared spectrum was devoid of any absorption corresponding to $\mathrm{NH}$ and $\mathrm{CO}$ groups, while the ${ }^{1} \mathrm{HNMR}$ spectrum proposed the structure of compound $\mathbf{1 2}$ (shown in Experimental).

The proposed pathway for the formation of compound 12 is illustrated in Scheme 6.

\section{Biological Activity}

The antimicrobial screening of some synthesized compounds was done using the Kirby-Bauer disc diffusion method. The possible antimicrobial activities of compounds 2, 3, 6, and 7 were investigated on four standard organisms including the Gram-positive bacteria, Staphylococcus aureus and Bacillus subtilis, and the Gram-negative bacteria, Escherichia coli, in addition to the fungus Aspergillus niger. The obtained results are presented in Table 1. Standard solutions of ciprofloxacin (Cip) and erythromycin (CN) as the antibacterial agent and amphotericin (Am) as the antifungal agent served as positive controls.

The obtained results emphasized the fact that "chemical agent symbolized" 2 exhibited medium activity only against "Aspergillus niger (fungus)" and that compound 7 revealed low activity only against Staphylococcus aureus (Gram- 
<smiles>COc1ccc(/C=C2\N=C(c3ccccc3)N(c3ccccc3)NC2=O)cc1</smiles>

(2)

(3)

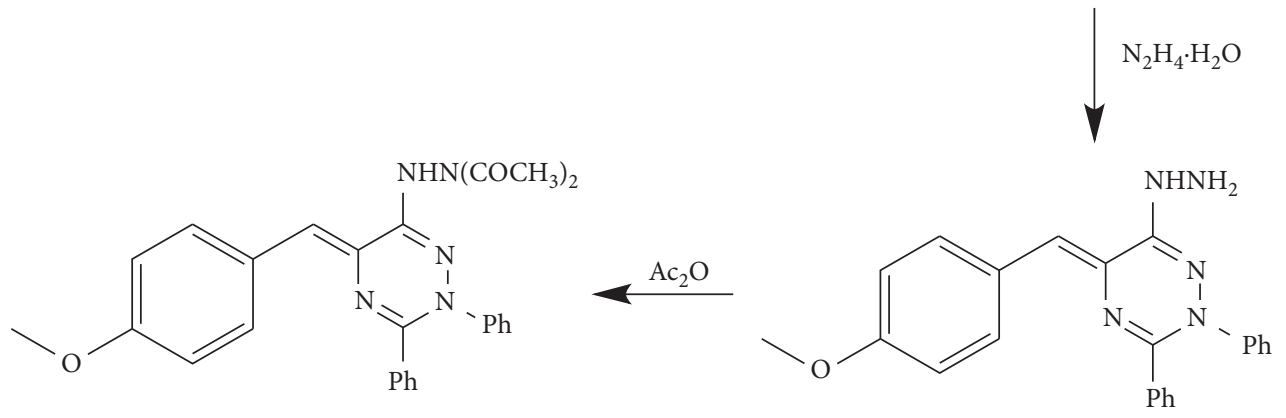

(5)

(4)

Scheme 2: Synthesis of new 1,2,4-triazine derivatives.

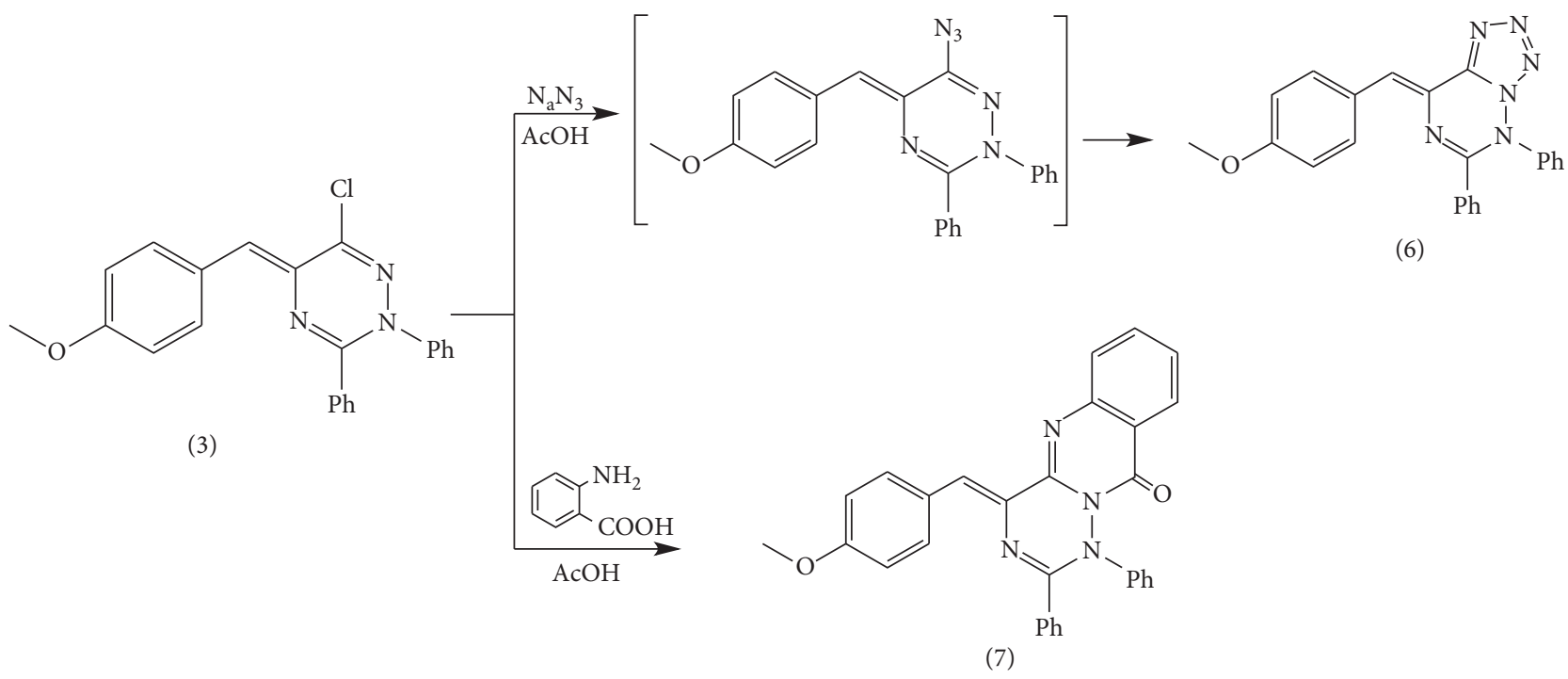

Scheme 3: Reaction of chlorotriazine 3 with a different nucleophile.

positive bacterium). The compounds 6 and 3 showed medium activity against both "Staphylococcus aureus" and "Bacillus subtilis" (Gram-positive bacterium).

\section{Experimental}

All the melting points are uncorrected and were measured on a Gallenkamp electric melting point apparatus. The infrared spectra were recorded using potassium bromide disks on a Thermo Fisher Scientific Nicolet FTIR 7600 (USA) infrared spectrometer at the Central Laboratory of Faculty of Science, Ain Shams University. ${ }^{1} \mathrm{HNMR}$ spectra were recorded at $300 \mathrm{MHz}$ on a Gemini
300 BB NMR spectrometer using tetramethylsilane (TMS) as the internal standard in deuterated dimethylsulphoxide (DMSO- $d_{6}$ ) at the main defense chemical laboratory. The mass spectra were recorded on a Shimadzu GCMS-QP-1000EX mass spectrometer operating at $70 \mathrm{eV}$ at the Regional Center for Mycology and Biotechnology of Al-Azhar University. The elemental analyses were performed on a PerkinElmer $2400 \mathrm{CHN}$ elemental analyzer at the Micro Analytical Center of Cairo University. The reactions were monitored by the thin layer chromatography on Merck Kiesel gel $60 \mathrm{~F}_{254}$ aluminum backed plates. The spots were detected by UV irradiation at $254-365 \mathrm{~nm}$ [18]. 
<smiles>COc1ccc(/C=C2\N=C(c3ccccc3)N(O)C2=O)cc1/C=C1\N=C(c2ccccc2)ONC1=O</smiles>

(Z-9)

Scheme 4: Preparation of 1,2,5-oxadiazine from azlactone (1).<smiles>CC=C1N=C(c2ccccc2)ON(C(C)=O)C1=O</smiles>

(10)<smiles>CC(C)=[W]</smiles>

$(\mathrm{Z}-8)$<smiles>CCOC(=O)[C@H](C)OC(=O)C(C)(C)C(=O)OCC(=O)O</smiles>

(11)

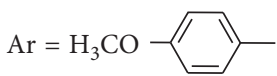

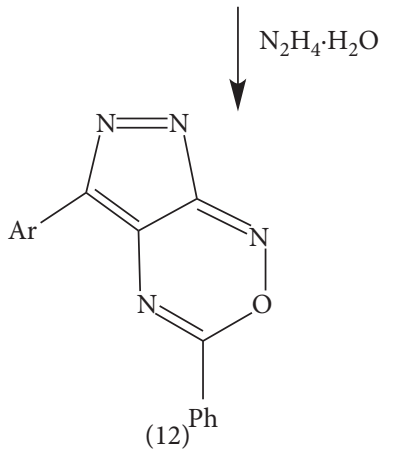

SCHeme 5: Reaction of 1,2,5-oxadiazine (8) with a carbon electrophile.

4.1. (Z)-4-(4-Methoxybenzylidene)-2-phenyloxazol-5(4H)-one (1). This compound is synthesized according to the method described in [16].

4.2. 5-(4-Methoxybenzylidene)-1,2-dihydro-2,3-diphenyl-1,2,4triazin-6(5H)-one (2). To a solution of oxazolone 1 (0.01 mol) in acetic acid $(30 \mathrm{ml})$, phenyl hydrazine $(0.01 \mathrm{~mol})$ and fused anhydrous sodium acetate $(0.2 \mathrm{gm})$ were added. The reaction mixture refluxed for $3 \mathrm{hrs}$. The solvent was distilled under reduced pressure, and the residue was poured onto crushed ice. The solid obtained was filtered off and recrystallized from ethanol to give compound 2. Yield 60\%; yellow crystals; m.p.
224-226 $6^{\circ} \mathrm{C}(\mathrm{EtOH}) ; \mathrm{IR}(\mathrm{KBr})\left(v, \mathrm{~cm}^{-1}\right): 3248(\mathrm{NH}), 3066$ $\left(\mathrm{CH}_{\text {arom }}\right), 2955\left(\mathrm{CH}_{\text {alkyl }}\right), 1708(\mathrm{C}=\mathrm{O})$, and $1638(\mathrm{C}=\mathrm{N})$; ${ }^{1} \mathrm{HNMR}\left(\mathrm{DMSO}-d_{6}\right) \delta: 3.98\left(\mathrm{~s}, 3 \mathrm{H}, \mathrm{OCH}_{3}\right), 6.61(\mathrm{~s}, 1 \mathrm{H},=\mathrm{CH})$, 6.76-7.56 (m, 10H, Ar-H), 8.06 (t, 2H, Ar-H), 8.27 (d, 2H, Ar$\mathrm{H}, J=6.6 \mathrm{~Hz}$ ), and 8.96 (br.s, $\mathrm{H}, \mathrm{NH}$, exchangeable); $\mathrm{MS}$ $(70 \mathrm{eV}) \mathrm{m} / \mathrm{z}(\%): 369\left(\mathrm{M}^{+}, 34\right), 327(4), 262(5), 103(18), 91(88)$, 77 (37), 65 (100), 52 (5), and 44 (10). Anal. calcd for $\mathrm{C}_{23} \mathrm{H}_{19} \mathrm{O}_{2} \mathrm{~N}_{3}$ (396.42): $\mathrm{C}$ (74.78); $\mathrm{H}$ (5.18); and $\mathrm{N}$ (11.37). Found: C (74.65); H (5.07); and N (11.12).

4.3. 5-(4-Methoxybenzylidene)-6-chloro-2,5-dihydro-2,3diphenyl-1,2,4-triazine (3). The mixture of $2(0.01 \mathrm{~mol})$ 


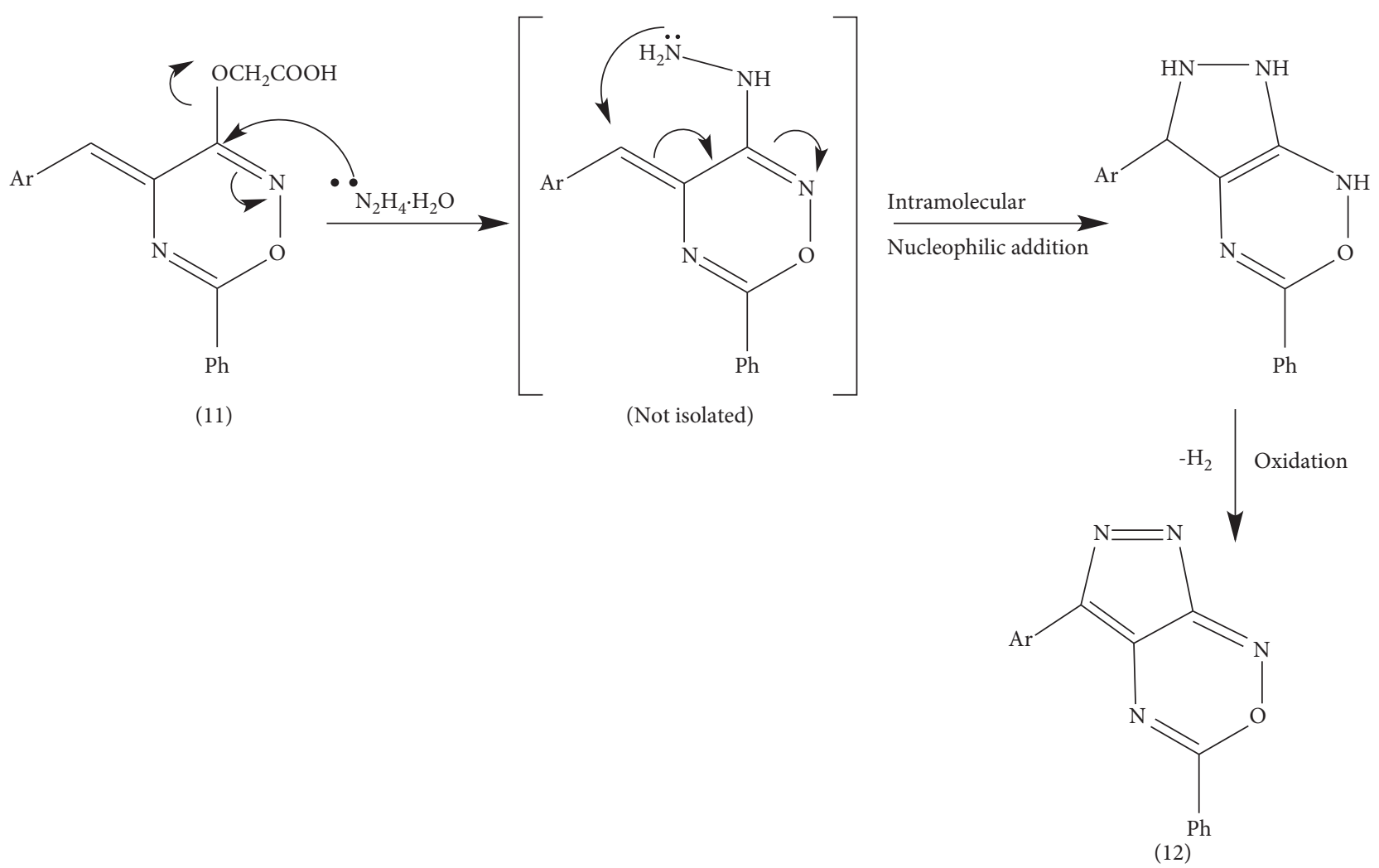

Scheme 6: Route of formation for compound 12.

TABle 1: Antimicrobial activity of selected compounds.

\begin{tabular}{lcccc}
\hline \multirow{2}{*}{ Sample no. } & \multicolumn{2}{c}{ Inhibition zone diameter (cm/gm sample) } \\
& Staphylococcus aureus $\mathrm{G}+$ & Bacillus subtilis $\mathrm{G}+$ & Escherichia coli G- & Aspergillus niger (fungus) \\
\hline $\mathbf{2}$ & 00 & 00 & 00 & 15 \\
$\mathbf{3}$ & 13 & 15 & 00 & 00 \\
$\mathbf{6}$ & 12 & 14 & 00 & 00 \\
7 & 11 & 00 & 00 & 00 \\
$\mathrm{Cip}$ & 15 & 20 & 20 & - \\
$\mathrm{CN}$ & 16 & 22 & - & - \\
Am & - & - & 20 & 17 \\
\hline
\end{tabular}

$\mathrm{Cip}=$ ciprofloxacin (antibacterial agent); $\mathrm{CN}=$ erythromycin (antibacterial agent); $\mathrm{Am}=$ amphotericin (antifungal agent). The concentration of all synthesized compounds and the reference was $5 \mathrm{mg} / 1 \mathrm{ml}$ of DMSO. Zone of inhibition: $0-16 \mathrm{~mm}=$ low; $14-16 \mathrm{~mm}=$ moderate; $<16 \mathrm{~mm}=$ high; $0=$ no inhibition

and phosphorus pentachloride $(0.01 \mathrm{~mol})$ in phosphorus oxychloride $(30 \mathrm{ml})$ refluxed on the water bath for $6 \mathrm{hrs}$. The reaction mixture was then poured gradually onto crashed ice. The solid obtained was filtered off and recrystallized from benzene to give compound 3. Yield 90\%; pale brown crystals; m.p. $160-162^{\circ} \mathrm{C}$ (benzene); IR $(\mathrm{KBr})\left(v, \mathrm{~cm}^{-1}\right): 3068\left(\mathrm{CH}_{\text {arom }}\right)$, $2935\left(\mathrm{CH}_{\text {alkyl }}\right)$, and $1600(\mathrm{C}=\mathrm{N}) ;{ }^{1} \mathrm{HNMR}\left(\mathrm{DMSO}-d_{6}\right) \delta: 3.72$ $\left(\mathrm{s}, \mathrm{OCH}_{3}\right), 6.86(\mathrm{~s}, 1 \mathrm{H},=\mathrm{CH})$, and 7.20-7.93 (m, 14H, Ar-H); MS (70 eV) m/z (\%): $387.75\left(\mathrm{M}^{+}, 7\right), 356$ (14), 328 (5), 235 (3), 194 (8), 104 (5), 93 (13), 77 (100), and 62 (30). Anal. calcd for $\mathrm{C}_{23} \mathrm{H}_{18} \mathrm{ON}_{3} \mathrm{Cl}$ (387.86): $\mathrm{C}$ (71.22); $\mathrm{H}$ (4.68); and $\mathrm{N}$ (10.83). Found: C (70.94); H (4.77); and N (10.51).

4.4. 1-(5-(4-Methoxybenzylidene)-2,5-dihydro-2,3-diphenyl1,2,4-triazin-6-yl)hydrazine (4). Compound 3 (0.01 mol) and hydrazine hydrate $(0.01 \mathrm{~mol})$ refluxed in ethyl alcohol $(20 \mathrm{ml})$ for $12 \mathrm{hrs}$. A solid product obtained after cooling to room temperature was filtered off and recrystallized from ethanol to give compound 4. Yield $88 \%$; colorless crystals; m.p. $170-172^{\circ} \mathrm{C}(\mathrm{EtOH})$; IR $(\mathrm{KBr})\left(v, \mathrm{~cm}^{-1}\right)$ : 3300, $3220(\mathrm{NH}$, $\left.\mathrm{NH}_{2}\right), 3065\left(\mathrm{CH}_{\text {arom }}\right), 2957\left(\mathrm{CH}_{\text {alkyl }}\right)$, and $1604(\mathrm{C}=\mathrm{N})$; ${ }^{1} \mathrm{HNMR}\left(\mathrm{DMSO}-d_{6}\right) \delta: 3.72\left(\mathrm{~s}, \mathrm{OCH}_{3}\right), 4.00$ (br.s, $\left.2 \mathrm{H}, \mathrm{NH}_{2}\right)$, $6.43(\mathrm{~s}, 1 \mathrm{H},=\mathrm{CH}), 7.85-7.95(\mathrm{~m}, 14 \mathrm{H}, \mathrm{ArH})$, and 8.97 (br.s, $1 \mathrm{H}, \mathrm{NH}$, exchangeable); MS (70 eV) $\mathrm{m} / z(\%): 383\left(\mathrm{M}^{+}, 2\right)$, 352 (1), 277 (5), 189 (8), 107 (8), 70 (100), 58 (2), and 44 (17). Anal. calcd for $\mathrm{C}_{23} \mathrm{H}_{21} \mathrm{~N}_{5} \mathrm{O}$ (383.45): $\mathrm{C}$ (72.04); $\mathrm{H}$ (5.52); and $\mathrm{N}$ (18.26). Found: C (71.66); H (5.21); and N (17.95).

4.5. $N^{\prime}$-(5-(4-Methoxybenzylidene)-2,5-dihydro-2,3-diphenyl1,2,4-triazin-6-yl)-N-acetylacetohydrazide (5). Solution of 4 
$(0.5 \mathrm{gm})$ in acetic anhydride $(15 \mathrm{ml})$ was heated under reflux for 6 hrs. The solvent was distilled off under reduced pressure, and the residue was poured onto crushed ice. The solid obtained was filtered off and recrystallized to give compound 5. Yield 90\%; white crystals; m.p. 108-110 ${ }^{\circ} \mathrm{C}$ $(\mathrm{EtOH}) ; \mathrm{IR}(\mathrm{KBr})\left(v, \mathrm{~cm}^{-1}\right): 3445(\mathrm{NH}), 3066\left(\mathrm{CH}_{\text {arom }}\right)$, 2956, 2923, $2852\left(\mathrm{CH}_{\text {alkyl }}\right), 1726,1701(\mathrm{C}=\mathrm{O})$, and 1640 $(\mathrm{C}=\mathrm{N}) ;{ }^{1} \mathrm{HNMR}\left(\mathrm{DMSO}-d_{6}\right) \delta: 2.28\left(\mathrm{~s}, 6 \mathrm{H}, 2 \mathrm{CH}_{3}\right), 3.83(\mathrm{~s}$, $\left.3 \mathrm{H}, \mathrm{OCH}_{3}\right), 7.00(\mathrm{~s}, 1 \mathrm{H},=\mathrm{CH}), 7.07-7.92(\mathrm{~m}, 14 \mathrm{H}, \mathrm{ArH})$, and 8.32 (br.s, $1 \mathrm{H}, \mathrm{NH}$, exchangeable); MS (70 eV) $\mathrm{m} / z(\%)$ : $467\left(\mathrm{M}^{+}, 8\right), 424$ (1), 368 (13), 360 (7), 352 (24), 327 (25), 273 (8), 235 (7), 194 (2), 141 (3), 91 (66), and 42 (100). Anal. calcd for $\mathrm{C}_{27} \mathrm{H}_{25} \mathrm{~N}_{5} \mathrm{O}_{3}$ (467.52): $\mathrm{C}$ (69.36); $\mathrm{H}$ (5.39); and $\mathrm{N}$ (14.98). Found: C (69.12); H (5.50); and N (15.18).

\subsection{Reaction of Chlorotriazine Derivative (3) with Some Nucleophilic Reagents}

4.6.1. General Procedure. Compound 3 (0.01 mol) and sodium azide or anthranilic acid $(0.01 \mathrm{~mol})$ refluxed in acetic acid "glacial" $(20 \mathrm{ml})$ for about $10-12 \mathrm{hrs}$. The solid product formed was filtered off and then recrystallized from ethanol to give compounds 6 and 7, respectively.

4.7. 8-(4-Methoxybenzylidene)-5,8-dihydro-5,6-diphenyltetrazolo[1,5-f][1,2,4]triazine (6). Yield 75\%; red crystals; m.p. 150-152 ${ }^{\circ} \mathrm{C}$; IR (KBr) $\left(v, \mathrm{~cm}^{-1}\right): 3065\left(\mathrm{CH}_{\text {arom }}\right), 2976,2837$ $\left(\mathrm{CH}_{\text {alkyl }}\right), 1600(\mathrm{C}=\mathrm{N})$, and $1573(\mathrm{~N}=\mathrm{N}) ;{ }^{1} \mathrm{HNMR}$ (DMSO$\left.d_{6}\right) \delta: 3.78\left(\mathrm{~s}, 3 \mathrm{H}, \mathrm{OCH}_{3}\right)$ and $6.76-7.94(\mathrm{~m}, 15 \mathrm{H}$, $\mathrm{ArH}+\mathrm{CH}=) ; \mathrm{MS}(70 \mathrm{eV}) \mathrm{m} / z(\%): 394\left(\mathrm{M}^{+}, 4.5\right), 354$ (37), 325 (2), 250 (11), 133 (5), 107 (18), 67 (4), and 48 (100). Anal. calcd for $\mathrm{C}_{23} \mathrm{H}_{18} \mathrm{~N}_{6} \mathrm{O}$ (394.43): $\mathrm{C}$ (70.04); $\mathrm{H}$ (4.60); and $\mathrm{N}$ (21.31). Found: C (70.31); H (4.73); and N (20.90).

4.8. 4-(4-Methoxybenzylidene)-1,2-diphenyl-1H-[1,2,4]triazino [6,1-b]quinazolin-10(4H)-one (7). Yield 80\%; off-white crystals; m.p. $128-130^{\circ} \mathrm{C}$; IR ( $\left.\mathrm{KBr}\right)\left(v, \mathrm{~cm}^{-1}\right): 3049\left(\mathrm{CH}_{\text {arom }}\right)$, 2944, $2844\left(\mathrm{CH}_{\text {alkyl }}\right), 1678(\mathrm{C}=\mathrm{O})$, and $1597(\mathrm{C}=\mathrm{N}) ;{ }^{1} \mathrm{HNMR}$ $\left(\mathrm{DMSO}-d_{6}\right) \delta: 3.70\left(\mathrm{~s}, \mathrm{OCH}_{3}\right), 6.42(\mathrm{~s}, 1 \mathrm{H},=\mathrm{CH})$, and 6.87-8.44 (m, 18H, ArH); MS (70 eV) m/z (\%): $470\left(\mathrm{M}^{+}, 7\right)$, 443 (3), 369 (6), 352 (6), 294 (15), 194 (1), 185 (3), 162 (4), 134 (3), 107 (7), 91 (64), and 43 (100). Anal. calcd for $\mathrm{C}_{30} \mathrm{H}_{22} \mathrm{~N}_{4} \mathrm{O}_{2}$ (470.52): $\mathrm{C}$ (76.58); $\mathrm{H}$ (4.71); and $\mathrm{N}$ (11.91). Found: C (76.17); H (4.33); and N (11.54).

4.9. (4Z)-4-(4-Methoxybenzylidene)-6-phenyl-2H-1,2,5-oxadiazin-3(4H)-one (8). To a solution of oxazolone $\mathbf{1}$ $(0.01 \mathrm{~mol})$ in pyridine $(30 \mathrm{ml})$, hydroxylamine hydrochloride $(0.01 \mathrm{~mol})$ was added. The reaction mixture refluxed for $3 \mathrm{hrs}$. The solvent was distilled under reduced pressure, and the residue was poured onto crushed ice. The solid obtained was filtered off and recrystallized to give compound $\mathbf{8}$. Yield 53\%; yellowish brown needles; m.p. 195-197 $\mathrm{C}$ (EtOH); IR $(\mathrm{KBr})\left(v, \mathrm{~cm}^{-1}\right): 3202(\mathrm{NH}), 3068\left(\mathrm{CH}_{\mathrm{arom}}\right), 2962\left(\mathrm{CH}_{\mathrm{alkyl}}\right)$, $1700(\mathrm{C}=\mathrm{O})$, and $1675(\mathrm{C}=\mathrm{N}) ;{ }^{1} \mathrm{HNMR}\left(\mathrm{DMSO}-d_{6}\right) \delta: 7.17$ (s, $1 \mathrm{H},=\mathrm{CH}), 6.92-8.31(\mathrm{~m}, 18 \mathrm{H}, \mathrm{ArH}+=\mathrm{CH})$, for Z-8a: 3.82 (s, 3H, $\mathrm{OCH}_{3}$ ), 9.81 (br.s, $1 \mathrm{H}, \mathrm{NH}$, exchangeable), for
Z-8b: 3.75 (s, $\mathrm{OCH}_{3}$ ), and 11.23 (br.s, $1 \mathrm{H}, \mathrm{OH}$, exchangeable); MS (70 eV) m/z (\%): $294\left(\mathrm{M}^{+}, 37\right), 278$ (40), 267 (1.5), 263 (1), 91 (88), 234 (1.1), 186 (6), 146 (12), 119 (16), 107 (1.3), 77 (97), 59 (15), and 40 (100). Anal. calcd for $\mathrm{C}_{17} \mathrm{H}_{14} \mathrm{O}_{3} \mathrm{~N}_{2}$ (294.31): $\mathrm{C}$ (69.38); $\mathrm{H}$ (4.79); and $\mathrm{N}$ (9.52). Found: C (68.98); H (4.52); and N (9.36).

4.10. 4-(4-Methoxybenzylidene)-2-acetyl-6-phenyl-2H-1,2,5oxadiazin-3(4H)-one (10). A solution of 8 (0.5 gm) in acetic anhydride $(20 \mathrm{ml})$ was heated under reflux for $3 \mathrm{hrs}$. The solvent was distilled off under reduced pressure, and the residue was poured onto crushed ice. The solid obtained was filtered off and recrystallized from ethanol to give compound 10. Yield $87 \%$; yellow crystals; m.p. $124-126^{\circ} \mathrm{C}(\mathrm{EtOH})$; IR $(\mathrm{KBr})\left(v, \mathrm{~cm}^{-1}\right): 3087\left(\mathrm{CH}_{\text {arom }}\right), 2940,2840\left(\mathrm{CH}_{\text {alkyl }}\right), 1775$, $1700(\mathrm{C}=\mathrm{O})$, and $1651(\mathrm{C}=\mathrm{N}) ;{ }^{1} \mathrm{HNMR}\left(\mathrm{DMSO}-d_{6}\right) \delta: 3.82$ (s, $\left.3 \mathrm{H}, \mathrm{CH}_{3}\right), 3.84\left(\mathrm{~s}, 3 \mathrm{H}, \mathrm{OCH}_{3}\right), 7.32(\mathrm{~s}, 1 \mathrm{H},=\mathrm{CH})$, and 7.04-8.30 (m, 9H, ArH); MS (70 eV) m/z (\%): $336\left(\mathrm{M}^{+}, 25\right)$, 294 (1.5), 251 (21), 234 (17), 186 (47), 159 (6), 143 (100), 107 (12), and 77 (29). Anal. calcd for $\mathrm{C}_{19} \mathrm{H}_{16} \mathrm{~N}_{2} \mathrm{O}_{4}$ (336.34): C (67.85); $\mathrm{H}$ (4.79); and N (8.33). Found: C (67.74); H (4.67); and $\mathrm{N}(7.95)$.

4.11. 2-(4-(4-Methoxybenzylidene)-6-phenyl-4H-1,2,5-oxadiazin-3-yloxy)acetic Acid (11). A mixture of compound 8 $(0.01 \mathrm{~mol})$ and ethyl chloroacetate $(0.01 \mathrm{~mol})$ refluxed in acetone $(25 \mathrm{ml})$ and potassium carbonate $(0.9 \mathrm{gm})$ for $10 \mathrm{hrs}$. The solvent was distilled off under reduced pressure, and the residue was poured onto ice water. The solid product was filtered off and recrystallized from diluted ethanol to give compound 11 . Yield $40 \%$; orange crystals; m.p. $280-282^{\circ} \mathrm{C}$ (dil. EtOH); IR (KBr) $\left(v, \mathrm{~cm}^{-1}\right): 3432(\mathrm{OH})$, $3073\left(\mathrm{CH}_{\text {arom }}\right), 2981,2846\left(\mathrm{CH}_{\text {alkyl }}\right), 1696(\mathrm{C}=\mathrm{O})$, and 1597 $(\mathrm{C}=\mathrm{N}) ;{ }^{1} \mathrm{HNMR}\left(\mathrm{DMSO}-d_{6}\right) \delta: 3.78\left(\mathrm{~s}, \mathrm{OCH}_{3}\right), 3.83(\mathrm{~s}, 2 \mathrm{H}$, $\left.\mathrm{CH}_{2}\right), 6.96-8.24(\mathrm{~m}, 9 \mathrm{H}, \mathrm{ArH}+=\mathrm{CH})$, and 11.99 (br.s, $1 \mathrm{H}$, $\mathrm{OH}$, exchangeable); MS (70 eV) $\mathrm{m} / z(\%): 352\left(\mathrm{M}^{+}, 12\right), 334$ (4.7), 294 (14), 235 (1.6), 117 (15), 77 (12), 69 (100), and 41 (34). Anal. calcd for $\mathrm{C}_{19} \mathrm{H}_{16} \mathrm{~N}_{2} \mathrm{O}_{5}$ (352.34): $\mathrm{C}$ (64.77); $\mathrm{H}$ (4.58); and $\mathrm{N}$ (7.95). Found: C (64.39); $\mathrm{H}$ (4.32); and $\mathrm{N}$ (7.68).

4.12. 5-(4-Methoxyphenyl)-3-phenylpyrazolo[3,4-c][1,2,5]oxadiazine (12). To a solution of compound $11(0.01 \mathrm{~mol})$ in ethyl alcohol $(20 \mathrm{ml})$, hydrazine hydrate $(0.015 \mathrm{~mol})$ was added. The reaction mixture refluxed for $6 \mathrm{hrs}$. The solvent was distilled under reduced pressure, and the residue was poured onto crushed ice. The solid obtained was filtered off and recrystallized from ethanol to give compound 12. Yield: $58 \%$; pink needles; m.p. $155-157^{\circ} \mathrm{C}(\mathrm{EtOH})$; IR $(\mathrm{KBr})(v$, $\left.\mathrm{cm}^{-1}\right): 3015\left(\mathrm{CH}_{\text {arom }}\right), 2937,2844\left(\mathrm{CH}_{\text {alkyl }}\right)$, and $1606(\mathrm{C}=\mathrm{N})$; ${ }^{1} \mathrm{HNMR}\left(\mathrm{DMSO}-d_{6}\right) \delta: 3.81\left(\mathrm{~s}, \mathrm{OCH}_{3}\right)$ and $7.02-8.61(\mathrm{~m}$, $10 \mathrm{H}, \mathrm{ArH}+=\mathrm{CH}) ; \mathrm{MS}(70 \mathrm{eV}) \mathrm{m} / z(\%): 304\left(\mathrm{M}^{+}, 8\right), 276(6)$, 227 (1), 195 (1.4), 185 (3), 119 (9), 107 (8), 91 (10), 77 (79), 70 (23), 57 (100), and 54 (12). Anal. calcd for $\mathrm{C}_{17} \mathrm{H}_{12} \mathrm{~N}_{4} \mathrm{O}_{2}$ (304.30): C (67.10); H (3.97); and N (18.41). Found: C (66.72); H (4.25); and N (18.12). 


\section{Data Availability}

The instrumental data including IR, mass, HNMR, and elemental analysis data used to support the findings of this study are included within the article.

\section{Conflicts of Interest}

The authors declare that they have no conflicts of interest.

\section{References}

[1] M. Kidwai, Y. Goel, and R. Kumar, "Synthesis of novel antibacterial cephalosphorin derivatives using microwaves," Indian Journal of Chemistry, vol. 37B, p. 174, 1998.

[2] B. S. Holla, R. Gonsalves, B. S. Rao, S. Shenoy, and H. N. Gopalakrishna, "Synthesis of some new biologically active bis-(thiadiazolotriazines) and bis-(thiadiazolotriazinyl) alkanes," Farmanco, vol. 56, no. 12, pp. 899-903, 2001.

[3] R. M. A. Rahman, J. M. Morsy, F. Hanafy, and H. A. Amene, "Synthesis of heterobicyclic nitrogen systems bearing the 1,2,4-triazine moiety as anti-HIV and anticancer drugs," Pharmazie, vol. 54, no. 5, pp. 347-351, 1999.

[4] M. W. Partridge and M. F. G. Stevens, "Pyrazolo-as-triazines. Part I," Journal of the Chemical Society C: Organic, vol. C, p. 1127, 1966.

[5] E. I. Abd and Z. K. Samii, "Synthesis and anti-inflammatory activity of some novel 1,3,4-oxadiazole derivatives," The Journal of Chemical Technology \& Biotechnology, vol. 53, p. 143, 1992.

[6] M. P. Hay, F. B. Pruijn, S. A. Gamage et al., "DNA-targeted 1,2,4-benzotriazine 1,4-dioxides: potent analogues of the hypoxia-selective cytotoxin tirapazamine," Journal of $\mathrm{Me}$ dicinal Chemistry, vol. 47, no. 2, pp. 475-488, 2004.

[7] W. P. Heilman, R. D. Heilman, J. A. Scozzie, R. J. Wayner, J. M. Gullo, and Z. S. Ariyan, "Synthesis and antihypertensive activity of novel 3-hydrazino-5-phenyl-1,2,4-triazines," Journal of Medicinal Chemistry, vol. 22, no. 6, pp. 671-677, 1979.

[8] J. G. Erickson, Chemistry of Heterocyclic Compounds, A. Wessberger, Ed., Vol. 10, Wiley, Hoboken, NJ, USA, 1956.

[9] R. L. Jones and J. R. Kershaw, "Biogensis of crabohydrates in wood," Reviews of Pure and Applied Chemistry, vol. 21, p. 23, 1971.

[10] K. M. Khan, S. Rahat, M. I. Choudhary et al., "Synthesis and biological screening of 2-substituted 5,6-dihydro-5-oxo-4H1,3,4-oxadiazine-4-propanenitriles and of their intermediates," Helvetica Chimica Acta, vol. 85, no. 2, pp. 559-570, 2002.

[11] M. J. Kornet, "Synthesis and anticonvulsant activity of 2-aryl3,4-dialkyltetrahydro-1,3,4-oxadiazines and 2-aryl-3,4-dialkyltetrahydro-1,3,4-oxadiazin-5-ones," Journal of Heterocyclic Chemistry, vol. 33, no. 6, pp. 2047-2049, 1996.

[12] R. P. Robinson and K. M. Donahue, "Synthesis of $N$-alkoxycarbonyl and $\mathrm{N}$-carboxamide derivatives of anti-inflammatory oxindoles," Journal of Heterocyclic Chemistry, vol. 31, no. 6, pp. 1541-1544, 1994.

[13] M. B. Gravestock, "Preparation of 8-oxo-3-oxa-1,4-diazabicyclo[4,2,0]oct-4-enes as penem and carba-penem intermediates," European Patent Application, vol. 265, p. 169, 1987.

[14] M. B. Gravestock, Chemical Abstracts, vol. 109, pp. 110-160, 1988.
[15] R. K. Smalley, Comprehensive Heterocycle Chemistry II, A. J. Boulton, Ed., vol. 6, pp. 681-694, Elsevier, Oxford, UK, 1996.

[16] B. Mayank and S. C. Lalit, "Synthesis and molecular modeling studies of some new derivatives of benzylidene-2-phenyl-1Himidazol-5(4H)-one," International Journal of Ayurveda and Pharmaceutical Chemistry, vol. 2, no. 1, 2014.

[17] C. K. Ingold, Structure and Mechanism in Organic Chemistry, p. 134, Bell and Sons, London, UK, 2nd edition, 1969.

[18] S. A. Ahmed, M. M. Hemdan, F. El-Mariah, and H. E. Hashem, "Synthesis of some quinazolinone derivatives Functionalized with N-3 heterocyclic side chain," Journal of Heterocyclic Chemistry, vol. 75, no. 7, pp. 1626-1633, 2018. 

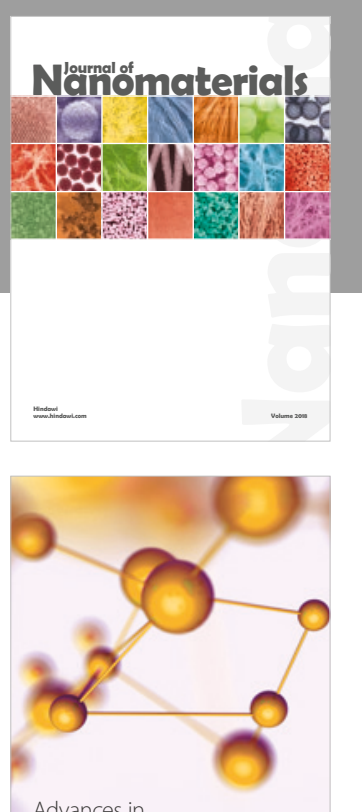

Physical Chemistry
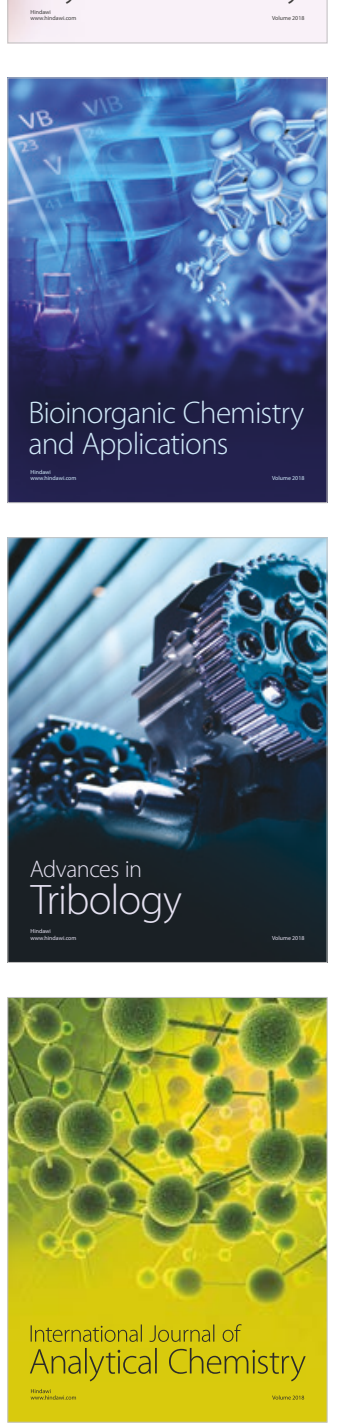

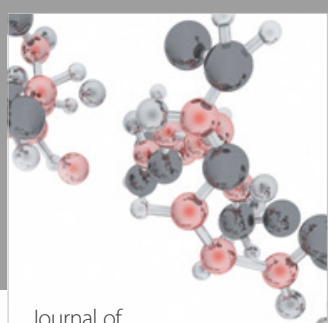

Analytical Methods

in Chemistry

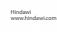

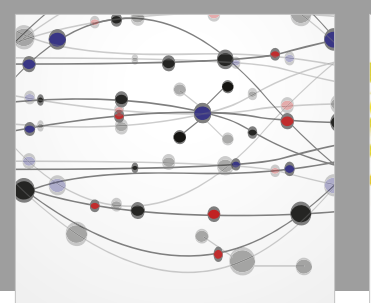

The Scientific World Journal

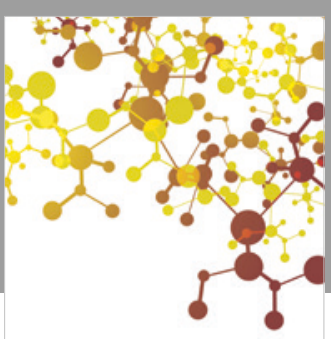

Journal of

Applied Chemistry
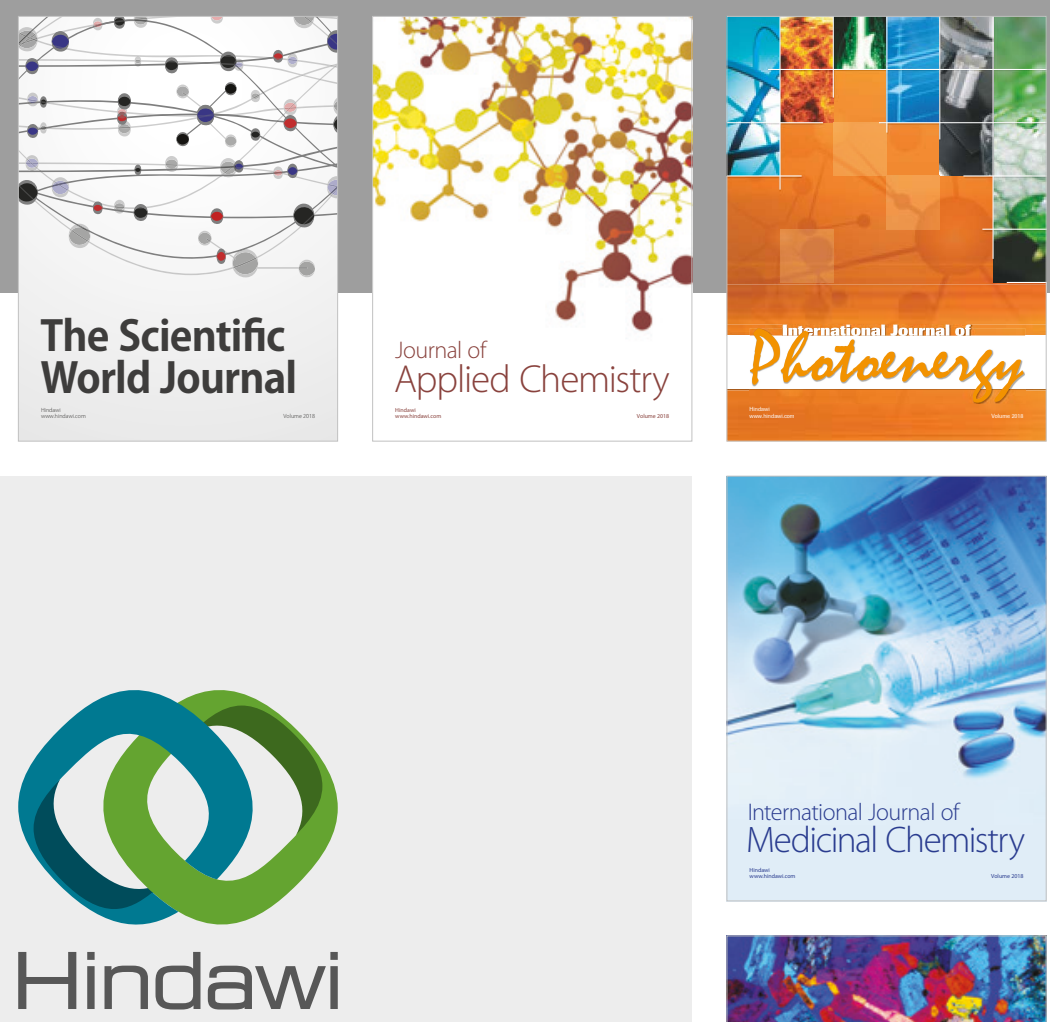

Submit your manuscripts at

www.hindawi.com
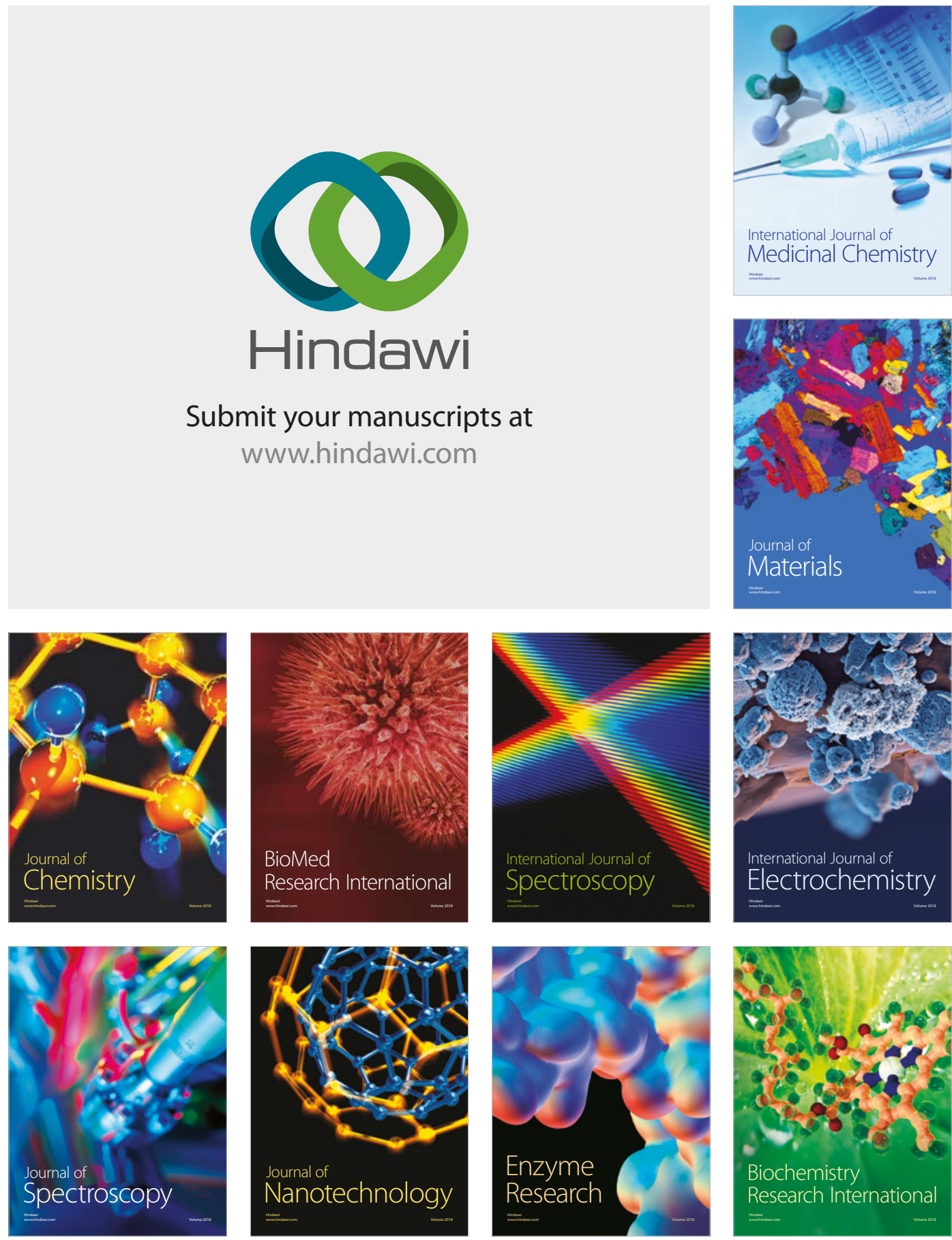
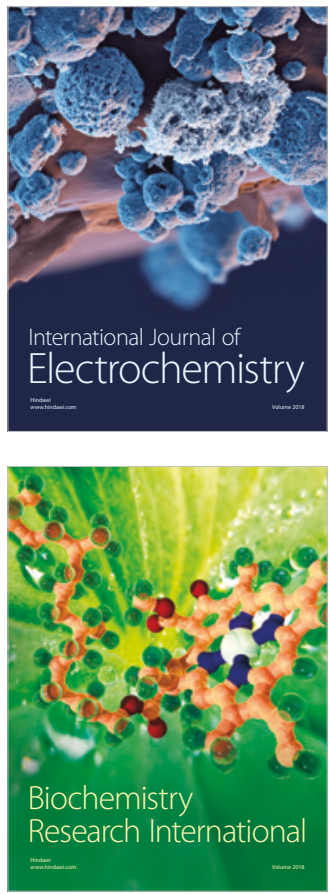